\title{
Metástases Cutâneas de Carcinoma de Células de Hürthle da Tiróide
}

\author{
Rui Tavares-Bello1, Carlos Tavares-Bello², Sónia Fernandes' ${ }^{1}$ Carlos Serra ${ }^{3}$, Óscar Tellechea ${ }^{4}$, Helena Garcia ${ }^{5}$ \\ 'Dermatology Service, Hospital dos Lusíadas, Lisbon, Lisbon, Portugal \\ 2Endocrinology Service, Hospital Egas Moniz, Lisbon, Lisbon, Portugal \\ ${ }^{3}$ Surgery Department, Hospital dos SAMS, Lisbon, Lisbon, Portugal \\ ${ }^{4}$ Dermatology Service, Hospitais da Universidade de Coimbra, Coimbra, Portugal \\ ${ }^{5}$ Pathology Service, Hospitais da Universidade de Coimbra, Coimbra, Portugal
}

RESUMO - Metástases cutâneas de neoplasias internas constituem um evento raro, ocorrendo em 0,9\% a 4,4\% em grandes estudos necrópsicos e atingindo $9 \%$ em grandes séries de doentes neoplásicos. Metástases cutâneas de carcinomas da tiróide são ainda mais raros e, entre eles, os de carcinomas foliculares foram mais raramente reportados, mais escassamente do que os de carcinomas papilares ou medulares.

Um Eurocaucasiano de 57 A de idade recorreu à consulta por pápula angiomatoide na área parietal do couro cabeludo, com cerca de 4 meses de evolução. O doente tinha sido submetido, 2 anos antes, a tiroidectomia total, complementada com radioterapia e diversos esquemas quimioterapêuticos por um carcinoma metastático de células de Hürthle da tiróide. A biópsia excisional da pápula permitiu estabelecer, com recurso a estudos imuno-histoquímicos, o diagnóstico de metástase cutânea de carcinoma folicular da tiróide. Os gânglios linfáticos, pulmões e os ossos constituem as mais prevalentes localizações à distância das metástases do carcinoma folicular da tiróide. Embora estas neoplasias representem até 12\% das neoplasias malignas da tiróide, metástases cutâneas destes tumores têm sido muito raramente reportadas. Estes tumores são habitualmente carcinomas bem diferenciados, com prognóstico favorável a longo termo e caracterizados histologicamente por estruturas foliculares com material colóide e variáveis anaplasia e distorção arquitectural.

No caso apresentado merecem destaque a morfologia angiomatoide da lesão metastática, classicamente associada a metástases de tumores de células renais e a alguns casos já relatados de tumores de células de Hürthle, bem como o comportamento agressivo e a evolução fatal verificados. O caso é ilustrado iconograficamente e uma breve revisão da literatura é efectuada.

PALAVRAS-CHAVE - Adenocarcinoma Folicular; Couro Cabeludo; Metástase Neoplásica; Neoplasias da Pele/secundária; Neoplasias da Tiróide.

\section{Scalp Metastasis from Follicular Hürthle-Cell Carcinoma of the Thyroid Challenges and Follow-up}

ABSTRACT - Overall, skin metastases from internal malignancies are a rare event, ranging from $0.9 \%$ to $4.4 \%$ in large autopsy studies and reaching $9 \%$ in large series of patients. Skin metastases from thyroid carcinoma are even rarer and, among them, follicular carcinomas have seldom been reported in this context, far less so than papillary and medullary carcinomas.

A 57-year-old Caucasian male presented with an angioma-like papule on the parietal area of the scalp with a 4-month history. The patient had endured 2 years previously total thyroidectomy, radiotherapy and several chemotherapeutical regimens for a metastatic Hürthle cell carcinoma of the thyroid gland. Excisional biopsy of the nodules established the diagnosis of metastatic (lung and liver) follicular cell carcinoma on plain histological and immunohistochemical grounds. Lymph nodes, lungs and bones are the most common sites of distant metastases of thyroid carcinomas. Although accounting for about $12 \%$ of all thyroid carcinomas, skin metastases from follicular carcinomas have however only rarely been reported. These tumours are usually well-

Correspondência: Rui Tavares Bello

Av. António Augusto Aguiar, 24- $8^{\circ}$ Dto

1050-016 Lisboa, Portugal

Email: dermoclinica@netcabo.pt
Recebido/Received

14 Outubro/October 2016

Aceite/Accepted

15 Março/March 2017 


\section{Caso Clínico}

-differentiated carcinomas, bearing a fair long-term prognosis and characterized pathologically by the presence of follicular structures and colloid material in the midst of diverse amounts of anaplasia and architectural disorganization. In our case, it is noteworthy the angioma-like morphology of the metastatic nodule, classically associated with renal cell carcinoma scalp metastases, as well as its aggressive nature which led eventually to a fatal outcome.

This case is ichnographically depicted and a review of the relevant literature is done.

KEYWORDS - Adenocarcinoma, Follicular; Neoplasm Metastasis; Skin Neoplasms/secondary; Scalp; Thyroid Neoplasms.

\section{INTRODUCTION}

Metastases to the skin from internal malignancies are rare, ranging from $0.9 \%$ to $4.4 \%$ in large autopsy series and reaching up to $9 \%$ in large series. ${ }^{1}$ In spite of the fact that thyroid carcinoma is the commonest endocrinological malignancy, ${ }^{2}$ its prevalence is nevertheless quite low, representing about $1 \%$ of all diagnosed cancers (non melanoma skin cancers excluded!) per year, in the USA ${ }^{3}$ and, overall, accounting for about $0.5 \%$ of all cancers in males and $1.5 \%$ in females. ${ }^{4}$ Follicular thyroid carcinoma (FTC) - the second most common subtype, following papillary thyroid carcinoma - accounts for $12 \%$ of all thyroid cancers. It tends to present with its peak incidence at 40-50 years of age and is more prevalent in areas of endemic iodine deficiency, suggesting that nodular goiter may predispose to its development. ${ }^{5}$ Although usually more aggressive than papillary thyroid carcinoma, FTC still carries an excellent long-term prognosis with a 20 year mortality rate of only $25 \%$, as reported in a 197 patients series. ${ }^{6}$ Although FTC's do have a propensity for vascular invasion and hematogenous dissemination, ${ }^{7}$ skin metastases have only scarcely been reported, circumstance that nevertheless constitute an ominous prognostic indicator. $^{8}$

We hereby report on a 57-year-old patient that developed an angioma-like scalp metastasis in the context of a widely disseminated follicular thyroid carcinoma, oncocytic variant (Hürthle cell carcinoma).

\section{CASE REPORT}

A 57-year-old Caucasian male was examined because of a $4 \mathrm{~mm}$ diameter erythematous papule on the right parietal region of his scalp that had slowly been enlarging for the last 4 months. Thought to be a senile angioma or a pyogenic granuloma, an unsuccessful attempt to "dry it" with a silver nitrate pencil had previously been tried by himself. Upon examination, a $4 \mathrm{~mm}$ bright red papule with an angiomatous-looking morphology was appreciated at the right parietal aspect of his scalp (Fig. 1). On palpation, the lesion had also a slightly indurate, dermal quality which prompted the need for an excisional biopsy.

Two years earlier, follicular thyroid carcinoma - oncocytic, Hürthle cell variant - had been diagnosed, superimposed on a 25 year duration multinodular colloid goiter. Total thyroidectomy was then performed, which was followed by adjuvant radioactive iodine-131 ablative therapy. They both proved unsuccessful since, unfortunately, metastatic spread to the lungs (1 year later) and to the

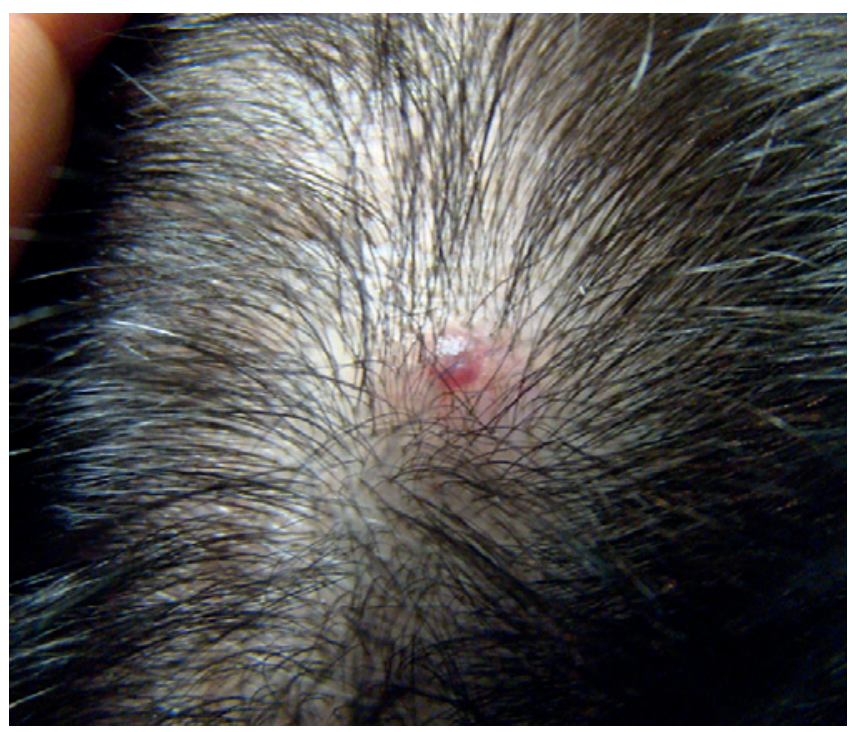

Figure 1 - Scalp angioma-like papule.

liver (two years later) always accompanied by sustained high, ever-rising serum thyroglobulin levels (from 15.9 to $22267 \mathrm{ng} / \mathrm{mL}$ ), ensued. During this time, apart from 3 iodine-131 ablative therapy sessions (cumulative dosing

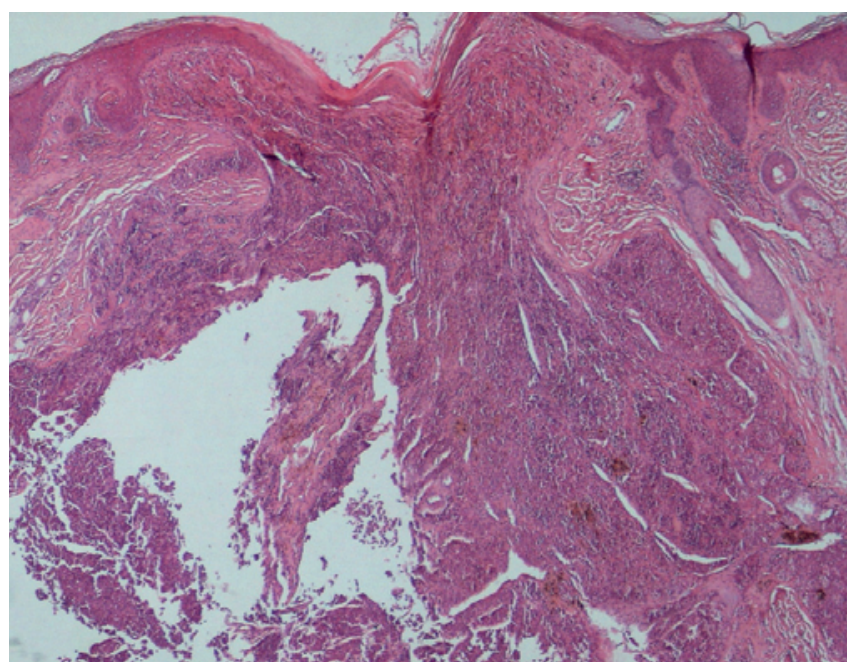

Figure 2 - Dermis occupied (and distorted) by an epithelial proliferation $(H \& E, x 40)$. 


\section{Caso Clínico}

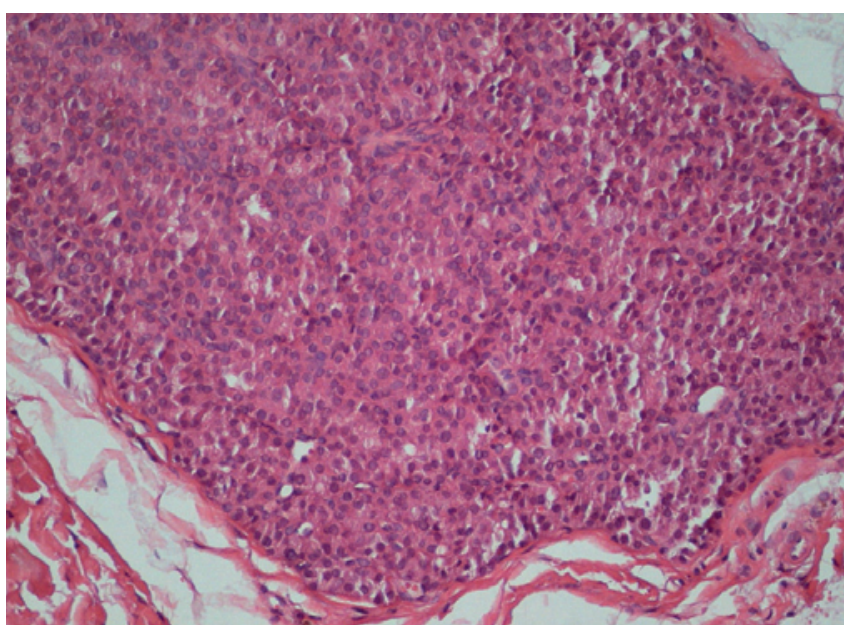

Figure 3 - Detailed epitelial proliferation (H\&E, x100).

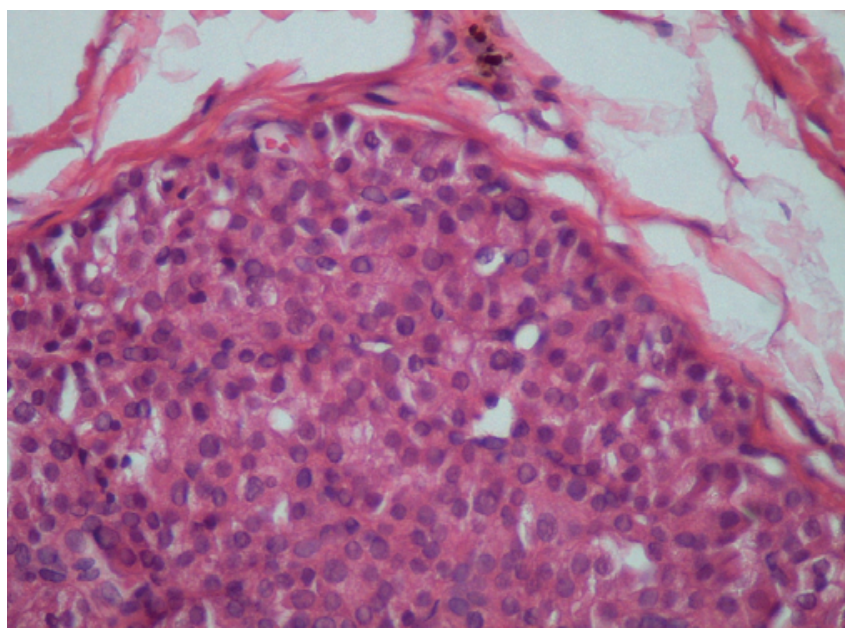

Figure 4a - A folicular pattern can be appreciated (H\&E, x200).

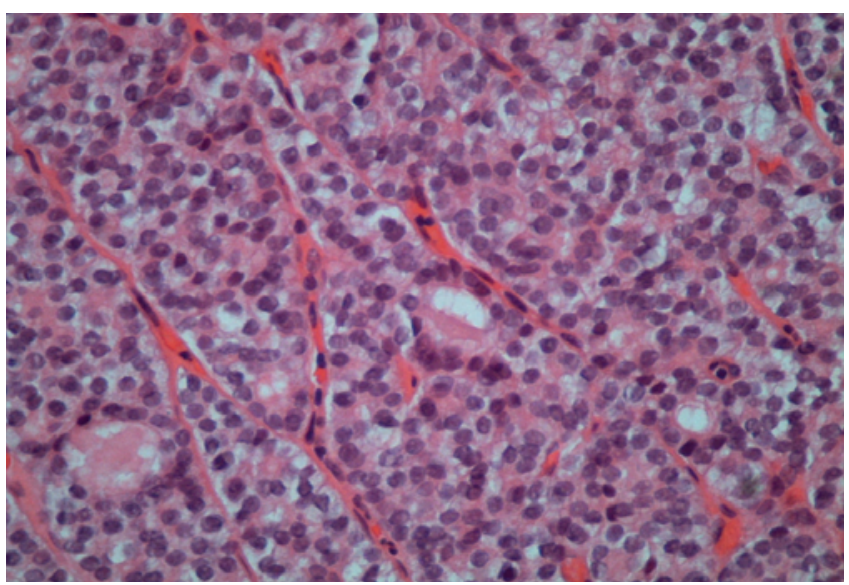

Figure $\mathbf{4 b}$ - Detail of the follicular structure of the proliferation $(\mathrm{H} \& \mathrm{E}$ x400)
$450 \mathrm{mCi}$ ) attempts, a number of radiofrequency ablation procedures on both liver and lung metastases were done, which proved unsuccessful.

Excisional biopsy of the scalp nodule established the diagnosis of metastatic follicular cell carcinoma (on both plain H\&E histological (Fig.s 2, 3, 4a and $4 b$ ) and on immunohistochemical slides (Fig.s $5 a, 5 b$ and 6 ). The presence of a dermal nodular epithelial proliferation with both cell solid aggregations and ill-defined follicular structures

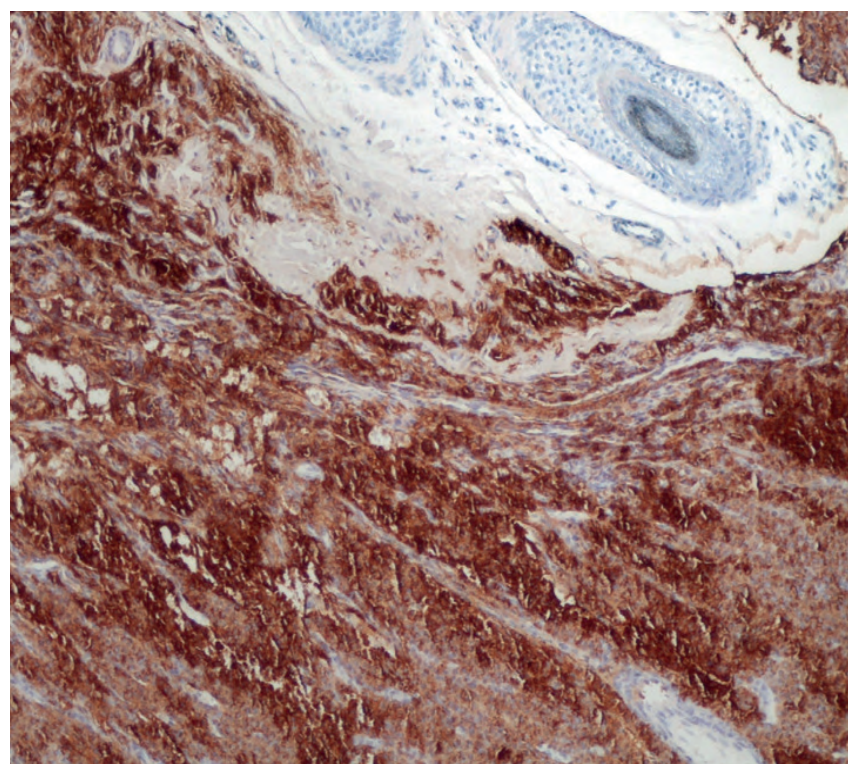

Figure $5 \mathrm{a}$ - Positive thyroglobulin immunostaining (TG, x100).

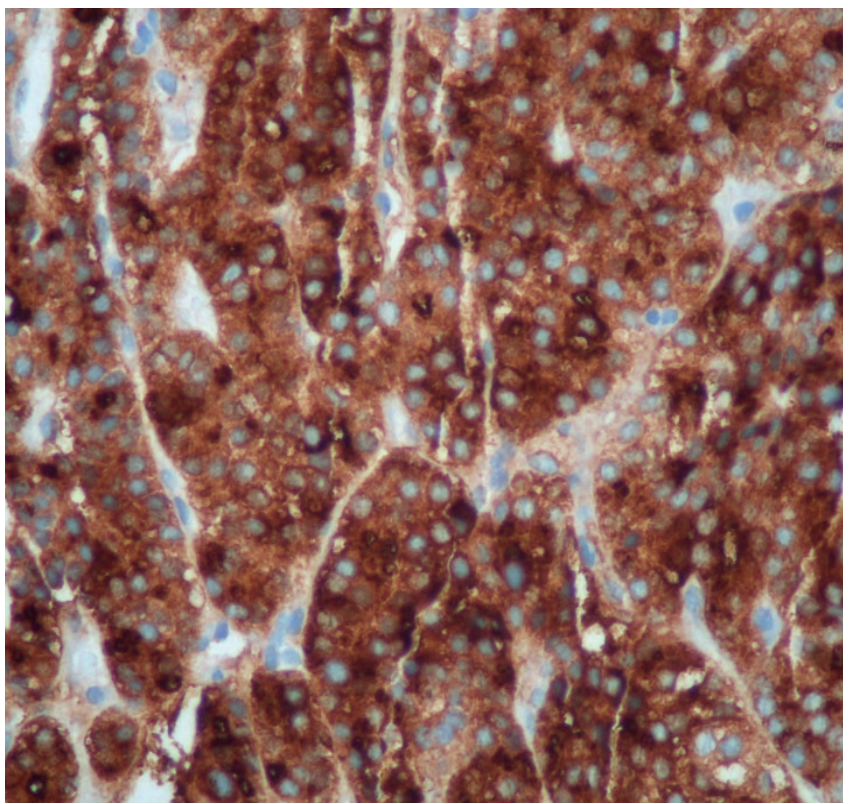

Figure 5b - Thyroglobulin immunostaining (TG, x400) 


\section{Caso Clínico}

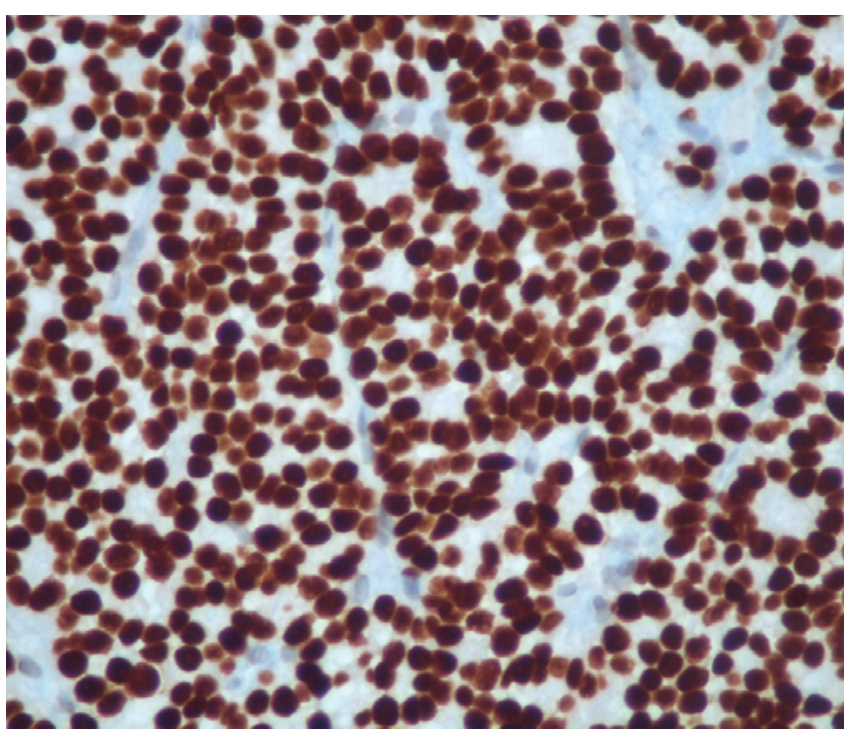

Figure $\mathbf{6}$ - Thyroid transcription factor-1 immunostaining (TTF-1, $\times 400$ )

was evident in HE sections; the cells were mildly pleomorphic, with eosinophilic cytoplasm and round to oval-shaped nuclei (Fig.s 2, 3, 4a and 4b). Immunoperoxidase staining analysis of the specimen showed thyroglobulin, thyroid transcription factor-1 (TTF-1) and CK19 full expression, CK 7 had a minimal expression while CK 20 and PSA had absence of labeling (Fig.s 5a,5b and 6).

From then on, selective liver chemoembolization (lipiodol and doxorubicin) and a systemic chemotherapy regimen with tyrosine kinase inhibitor sorafenib, were performed with major adverse events and without significant benefits. By that time and in an attempt to personalize therapy for an improved outcome, a thyroid carcinoma molecular study had been done which was negative both for BRAF (exons 11 and 15), HRAS (exon 2) and KRAS (exon 2) mutations and for RET/PTC, PAX8 PPARg gene rearrangements. Recently, adding to the previously diagnosed metastatic locations, skeletal metastases at the thoracic portion of the spine, on the left humerus and scapula were also detected, which have prompted for initiation of second line systemic sunitinib. Again, these attempts did not succeed and, eventually the patient died, 7 and a half years after the initial diagnosis.

\section{DISCUSSION}

Primary thyroid malignancies are not rare, accounting for approximately $1 \%$ of all newly diagnosed cancers. Differentiated thyroid carcinomas are the most frequent thyroid malignant neoplasms, accounting papillary and follicular carcinomas for the majority of the cases (80 and $12 \%$ respectively). ${ }^{8}$ Follicular carcinoma lacks the typical microscopic nuclear features of papillary carcinoma and frequently shows transcapsular and/or signs of vascular invasion. Hürthle cell carcinoma is considered a variant of follicular carcinoma that is pathologically characterized by abundance of follicular cells with oncocytic features (> $75 \%$ of tumor mass). ${ }^{9}$ Some authors consider the oncocytic variant a distinct subtype of Thyroid cancer due to its unique gross, microscopic, behavioral and cytogenetic features. ${ }^{10}$ Despite being distant metastasis and disease recurrence more common in patients with Hürthle cell carcinoma, ${ }^{11}$ data regarding skin metastases are still scarce.

Cutaneous metastases of differentiated thyroid carcinomas are quite unusual. They are even more rarely the initial presentation of a hitherto unknown thyroid primary malignancy, ${ }^{12}$ usually heralding an already widely disseminated disease.

In particular, the rarity of follicular thyroid carcinoma (FTC) metastatic to the skin is reflected by the fact that only 18 cases have so far been reported in the English language literature (8). ${ }^{13-18}$ Overall, females outnumber males (12:6); the mean age at presentation is about 65 (41-85), with locations of the skin metastases being the scalp (13 pts), neck (3 pts), face (2 pts) and others (2 pts). ${ }^{13-18} \mathrm{Cli}$ nically, they mostly present as asymptomatic skin-colored or red, angioma-like, firm and mobile dermal and subcutaneous papules and nodules that range in size from a few millimeters to several centimeters in diameter and that can occasionally erode and ulcerate both superficially and deeply, into the bone. ${ }^{19}$ A vascular appearance has indeed been identified in these lesions, to the point of even showing a pulsatile character upon Doppler echography. ${ }^{20}$ In the differential diagnosis, several benign and malignant lesions should be evoked, including angioma, pyogenic granuloma, Kaposi's sarcoma, angiosarcoma, renal cell and hepatocarcinoma scalp metastases. ${ }^{21}$

Final diagnosis is however established by histological examination of a tissue specimen with additional immunohistochemical and/or EM approaches, in order to clearly ascertain the nature and origin of the primary malignancy. Fine needle aspiration cytology has also been successfully used in this context. ${ }^{15}$ With regard to plain HE histological sections, in a nodular dermally located lesion with an epithelial phenotype, several other diagnoses should be ruled out, including adnexal skin tumors, metastatic prostate, bronchopulmonary and gastrointestinal adenocarcinoma. In our patient's case, the known existence of a widely metastatic follicular thyroid carcinoma led us to value it as the probable primary tumor. Such hypothesis was further corroborated by thyroglobulin, TTF1 and CK19 positive labeling. On the other hand, the negative or faintly positive focal immunolabeling with CK7, CK20 and PSA allowed us to rule out respectively lung, gastrointestinal and prostatic origins.

Metastatic disease is the primary cause of death in follicular thyroid carcinoma. Age above 45, Hürthle cell variant, primary tumor size exceeding $4 \mathrm{~cm}$, extrathyroidal extension and the presence of distant metastasis at presentation usually portend a worse prognosis. ${ }^{22}$ However, even when faced with disseminated malignancy, with 
appropriate management, long-term survival rates of up to $43 \%$ have been reported. ${ }^{23}$

Our patient did comply with the literature data as far as age; as a long lasting predisposing condition - multinodular colloid goiter; as clinical presentation, both in what location and morphology are concerned; as the uniformly unresponsiveness of the several chemotherapy regimens systemic and regional- that have been tried and, lastly, as far as clinical aggressiveness and ominous course.

Scalp is indeed a distinct skin area characterized by a rich dermal vasculature; hence, not surprisingly, it is a site of varied secondary neoplasms. In fact, lung, breast, colorectal and renal carcinomas, among others, have been reported to metastasize to the scalp. ${ }^{24}$ Metastatic scalp lesions are usually a serious diagnostic challenge. As they can greatly vary in appearance, a high index of clinical suspicion is required in order not to miss the diagnosis and further compromise patient's survival chances.

In sum, the case of a 57-year-old male patient with a metastatic Hürthle cell follicular thyroid carcinoma that presented with a scalp dermal papule is reported. In our patient's case, it is noteworthy the morphology of the papule that easily evoked a vascular lesion; the overtly aggressive nature of the primary, probably due its oncocytic nature and, finally, the fact that the presence of a skin metastasis usually portends a dismal prognosis.

Conflitos de interesse: Os autores declaram não possuir conflitos de interesse.

Suporte financeiro: $O$ presente trabalho não foi suportado por nenhum subsídio ou bolsa.

Confidencialidade dos dados: Os autores declaram ter seguido os protocolos do seu centro de trabalho acerca da publicação dos dados de doentes.

Protecção de pessoas e animais: Os autores declaram que os procedimentos seguidos estavam de acordo com os regulamentos estabelecidos pelos responsáveis da Comissão de Investigação Clínica e Ética e de acordo com a Declaração de Helsínquia da Associação Médica Mundial

Conflicts of interest: The authors have no conflicts of interest to declare.

Financing Support: This work has not received any contribution, grant or scholarship.

Confidentiality of data: The authors declare that they have followed the protocols of their work center on the publication of data from patients.

Protection of human and animal subjects: The authors declare that the procedures followed were in accordance with the regulations of the relevant clinical research ethics committee and with those of the Code of Ethics of the World Medical Association (Declaration of Helsinki).

\section{REFERENCES}

1. Lookingbill DP, Spangler N, Helm KF. Cutaneous metastases in patients with metastatic carcinoma: a retrospective study of 4020 patients. J Am Acad Dermatol.
1993;29:228-36.

2. Sreedharan S, Pang CE, Chan GS, Soo KC, Lim DT. Follicular thyroid carcinoma presenting as axial skeletal metastases. Singapore Med J. 2007; 48:640-4.

3. Parker SL, Tong T, Bolden S, Wingo PA. Cancer statistics 1996. CA Cancer J Clin. 1996;46:5-27.

4. Sherman SI. Thyroid carcinoma. Lancet. 2003;361: 500-1.

5. Maitra A, Abbas AK. The endocrine system. In: Kumar V, Abbas, AK, Fausto N, Robbins SL Cotran RS, editors. Pathological basis of disease. 7nd ed. New Delhi: Harcourt Ind; 2003. p. 1155-1226.

6. Hay ID. Papillary thyroid carcinoma. Endocrinol Metab Clin North Am. 1990; 19:545-76.

7. Grebe SK, Hay ID. Follicular thyroid cancer. Endocrinol Metab Clin North Am. 1995; 24:761-802.

8. Aschebrook-Kilfoy B, Ward MH, Sabra MM, Devesa SS. 2011 Thyroid cancer incidence patterns in the United States by histologic type, 1992-2006. Thyroid, 2011, 21:125-34.

9. Hedinger C, Williams ED, Sobin LH. Histological Typing of Thyroid Tumours. $2^{\text {nd }}$ ed. Originally published by the World Health Organization as no. 11 in the International Histological Classification of Tumours series. New York: Springer-Verlag; 1988.

10. Rosai J, Carganio ML, Delellis RA. Tumors of the Thyroid Gland. Washington: Armed Forces Institute of Pathology; 1992.

11. Grebe SK, Hay ID. Thyroid cancer nodal metastases: biologic significance and therapeutic considerations. Surg Oncol Clin North Am. 1996;5:43-63.

12. Dahl PR, Broadland DG, Goellner JR, Hay ID. Thyroid carcinoma metastatic to the skin: A cutaneous manifestation of a widely disseminated malignancy. J Am Acad Dermatol. 1997; 36:531-7.

13. Caron P, Moreau-Cabarrot A, Gorquet B, Bazex,I. Cutaneous metastasis from follicular carcinoma of the thyroid gland. Thyroid. 1993;3:235-7.

14. Quinn TR, Duncan LM, Zembowicz A, Faquin,WC. Cutaneous metastases of follicular thyroid carcinoma: a report of four cases and a Review of the Literature. Am J Dermatopathol, 2005;27:306-12.

15. Agarwal S, Rao S, Arya A, Gupta K, Arora R, et al. Follicular thyroid carcinoma with metastasis to skin diagnosed by fine needle aspiration cytology. Indian J Pathol Microbiol, 2008;51:430-1.

16. Prasoon D. Follicular carcinoma of thyroid gland presenting as scalp metastasis. Acta Cytologica. 1998;42:451.

17. Cupisti K, Ramp U, Raffel A, Krausch M, Rehders A, et al. Multiple giant scalp metastases of a follicular thyroid carcinoma. World J Surg Oncol. 2008;6:82.

18. Tronnier M, Winzer $M$, Wolff $\mathrm{HH}$. Cutaneous metastasis from follicular thyroid carcinoma: histology, immunohistology and electron microscopy. A report of two cases. Dermatologica. 1991;183:286-9. 


\section{Caso Clínico}

19. Shamin MS, Khursheed F, Bari ME Chisti KN, Enam SA. Follicular thyroid carcinoma presenting as solitary skull metastases. Report of Two Cases. J Pak Med Assoc. 2008; 58:575-7.

20. Fukunari N, Nagahama M, Sugino K, Mimura T, Ito K, Ito K. Clinical evaluation of color Doppler imaging for the differential diagnosis of thyroid follicular lesions. World J Surg., 2004; 28:1261-1265.

21. Carion B, Charbonnel B, Heymann MF, Bridji,B. Métástase cutanée d un carcinome vésiculaire de la thyrö̈de.
Presse Méd. 2000;29:1557-8.

22. Shaha AR, Loree TR, Shah JP. Prognostic factors and risk group analysis in follicular carcinoma of the thyroid. Surgery. 1995;118:1131-8.

23. Shaha AR, Shah JP Loree TR. Differentiated thyroid cancer presenting initially with distant metastasis. Am J Surg. 1997; 174:474-6.

24. Arslan S, Arslan E. Scalp metastases from thyroid carcinomas: review of clinical and pathological features. J Med Updates. 2014;4:71-6. 